\title{
Indirect Spectrophotometric Determination of Thiamine Hydrochloride in Presence of Sulphite Via Chromium-1,5- Diphenylcarbazide Complex
}

\author{
Najih H. Shekho \\ Bassima A. Abed Al-Hadi \\ Department of Chemistry \\ College of Science \\ University of Mosul \\ Lamya A. Sarsam
}

E-mail: Najihshiko@yahoo.com

Bassima_705Mo@yahoo.com

luma_sarsam@yahoo.com

(Received 16/9/2012 ; Accepted 7/11/2012)

\begin{abstract}
A simple, rapid, accurate and precise spectrophotometric method is proposed for the determination of thiamine hydrochloride (Vitamin $\mathrm{B}_{1}$ ) in both pure form and in its pharmaceutical formulations. The method is based on the oxidation-reduction reaction between vitamin $\mathrm{B}_{1}$ and known amount of chromate $\mathrm{CrO}_{4}{ }^{-2}$ in acidic medium of $2 \mathrm{~N}$ $\mathrm{H}_{2} \mathrm{SO}_{4}$. Then, the excess of chromate is measured via 1,5-diphenylcarbazide which gives a pinkish-violet, water soluble and stable complex and exhibits maximum absorption at 543 $\mathrm{nm}$, with a molar absorptivity of $1.5 \times 10^{4} 1 . \mathrm{mol}^{-1} \cdot \mathrm{cm}^{-1}$, Sandell's sensitivity index of $0.02248 \mu \mathrm{g} . \mathrm{cm}^{-2}$ and a relative standard deviation of \pm 0.31 to $\pm 0.57 \%$, depending on the concentration level. Beer's law is obeyed in the concentration range from 0.4 to $40 \mu \mathrm{g}$. $\mathrm{ml}^{-1}$ of thiamine hydrochloride. The present method has been developed for the determination of thiamine hydrochloride in the presence of sulphite. The proposed method has been applied successfully to the determination of vitamin $B_{1}$ in pharmaceutical preparations.
\end{abstract}

Keywords: Thiamin hydrochloride, sulphite, spectrophotometry, 1,5-diphenylcarbazide.

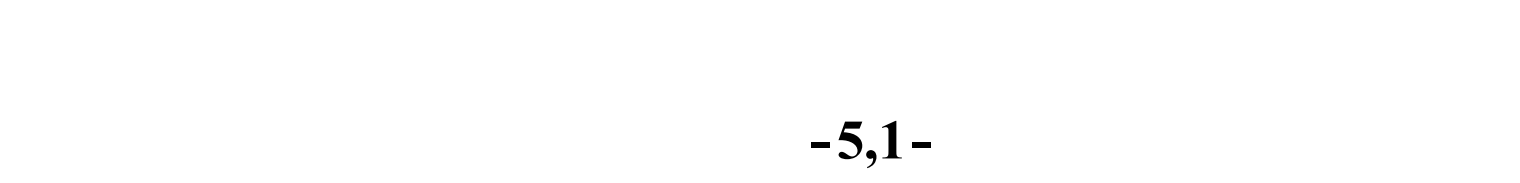

lll

قم اقتراحطريقة طيفية بسطة،سريعة، دقيقة ومتوافقة لقدير هيدروكلوريد الثيلمين (فيتلمين B.

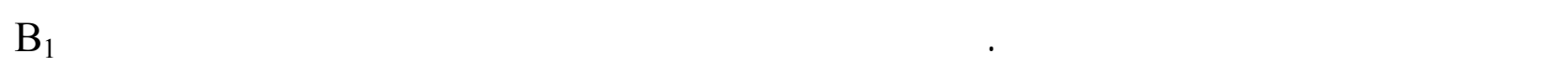
والكروملت الكب غير المختزلة من الكروملت مع الكلثف العضوي 5,1 - ثنائي فنيل كاربازيد لتكوين معقد وردي بفسجي، مسنقر وذائب في الماء والذي يطي أعلى لمتصاص عند الطول الموجي 543 نانوميتر. كانت 
المتصاصية المولارية 10×1.5 لترمول -10سم -1 ودلالة ساندل للمسلسية 0.02248 مايكروغرله.سم -2 والانحرف القيلسي النسبي في مدى aن 土 0.31 إلى 土 0.57 اعتمادا على مستوى التركيز. كانت حدود

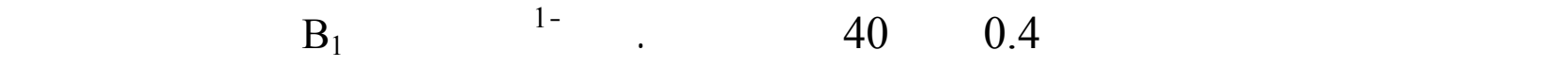
المقترحة لققدير هيدروكلوريد الثيلمين بوجود الكبريتيت. والطريقة المقترحةطبقت بنجاح لقدير فيتلمين في المستحضرات الصيدلانية. الكاملت الدالة: هيدروكلوريد الثيلمين، الكبريتيت،طيف الامتصاص، 5,1 - ثنائي فنيل كاربازيد.

\section{INTRODUCTION}

Thiamine or thiamin (British Pharmacopeia, 2007), named as the "thio-vitamin" (sulfur-containing vitamin) is a water-soluble vitamin of the B complex, previously known as vitamin $B_{1}$ or aneurine. It was isolated and characterized in 1920 and thus was one of the first organic compounds to be recognized and discovered as a vitamin, therefore it is named $\mathrm{B}_{1}$ (Bettendorff et al., 1996). There are five known natural thiamine phosphate derivatives (Bettendorff et al., 2007): Thiamine monophosphate (ThMP), thiamine diphosphate (ThDP), also sometimes called thiamine pyrophosphate (TPP), thiamine triphosphate (ThTP), recently discovered adenosine thiamine triphosphate (AThTP), and adenosine thiamine diphosphate (AThDP). All living organisms use thiamine in their biochemistry, but it is only synthesized in bacteria, fungi, and plants. Animals must obtain it from their diet and thus, for them, it is an essential nutrient. People need it to form adenosine triphosphate (ATP), which every cell of the body uses for energy (Bettendorff and Wins, 2009).

Thiamine structure contains an aminopyrimidine ring and a thiazole ring with methyl and hydroxyethyl side chains linked by a methylene bridge. It is soluble in water, methanol, and glycerol and practically insoluble in acetone, ether, chloroform and benzene. It is stable in acidic solution and during frozen storage, but it is unstable in alkaline solution, heat, and when it is exposed to ultraviolet light and gamma irradiation (Thornalley, 2005).<smiles>Cc1ncc(C[n+]2csc(CCO)c2C)c(N)n1</smiles>

Thiamine hydrochloride

$\mathrm{C}_{12} \mathrm{H}_{17} \mathrm{ON}_{4} \mathrm{SCl} . \mathrm{HCl}$

$\mathrm{Mw}=337.27 \mathrm{~g} /$ mole

IUPAC name: 2-[3-[(4-Amino-2-methyl-pyrimidin-5-yl)methyl]-4-methyl-thiazol-5yl] ethanol

Thiamine is sometimes called an "anti-stress" vitamin because it may strengthen the immune system and improve the body's ability to withstand stressful conditions. In mammals deficiency results in Korsakoff's syndrome, optic neuropathy, and a disease 
called beriberi that affects the peripheral nervous (polyneuritis) and/or cardiovascular system (Spinazzi et al., 2010). Thiamine deficiency has a potentially fatal outcome if it remains untreated. In less severe cases, nonspecific signs include malaise, weight loss, irritability and confusion (Webb et al., 2007). Sulphites are widely used in foods that include dried fruit and vegetables, wine, soft drinks, juices and meat products, such as sausages and hotdogs to prevent melanosis (black spot) on shrimp and lobster, to "condition" dough bleach food starches and inhibit "browning" in bottled lemon juice and virtually all processed potatoes. In all food products containing at least $10 \mathrm{ppm}$ of sulphite, sulphite will attack thiamine at the methylene bridge in the structure, cleaving the pyrimidine ring from the thiazole ring. The rate of this reaction is increased under acidic conditions also thiamine is degraded by thermolabile thiaminases (present in raw fish and shell fish) (Kappler et al., 2000). Some thiaminases are produced by bacteria. Bacterial thiaminases are cell surface enzymes that must dissociate from the membrane before being activated, the dissociation can occur in ruminants under acidotic conditions (Makarchikov et al., 2003). Rumen bacteria also reduces sulphate to sulphite, therefore high dietary intakes of sulphate can have thiamine-antagonistic activities (Begley et al., 2008).

Several Spectrophotometric methods have been used for the determination of thiamine, such as the determination of vitamin $\mathrm{B}_{1}$ with 12-tungstophosphoric acid by using resonance rayleigh scattering method (Zhiping et al., 2012), zero-crossing derivative spectrophotometry (Mahmure and Ikbal, 2002), partial least-squares regression (Abera'sturi et al., 2002), parallel factor analysis (Jahanbakhsh and Bahman, 2005), UVvisible spectrophotometry and genetic algorithm based multivariate calibration methods (Ozdemir and Dinc, 2004), horseradish as catalyst in the presence of hydrogen peroxide (Khan et al., 2009), triphenylmethane acid dyes (Shaopu et al., 2002), selective optosensor for UV-photometric (Barrales et al., 1998), UV-photodegradation in a single-line flowinjection assembly (Calatayud and Danet, 1994), multicommuted flow system (Rocha et al., 2003), implementation of flow-through solid phase spectroscopic transduction with photochemically induced fluorescence (Javier et al., 2005). Other methods depend on the inhibitory effect of thiamine on the hemoglobin-catalyzed reaction of $\mathrm{H}_{2} \mathrm{O}_{2}$ with acid chrome blue K (Yahong and Fengshou, 2010), a flow-injection spectrophotometric method has been also used for the determination of vitamin $B_{1}$ (Clezio et al., 1999).

1,5-Diphenylcarbazide (DPC) is an organic compound usually used in analytical chemistry for colorimetric measurements. It exhibits many useful properties and used as an artificial donor during charge separation in photochemical reactions and also photosynthesis electron transport (Sandell,1959). It is well known that chromate-1,5diphenylcarbazide chelate shows an intense pinkish-violet colour at $\mathrm{pH} 0.2$. On the other hand, thiamine reduced chromate to chromium (III) then the excess of chromate reacted with 1,5-diphenylcarbazide (Marczenko, 1976).

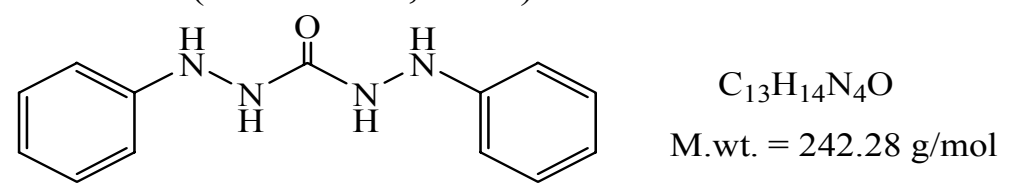

1,5-Diphenyl carbazide

The purpose of this work is to make use of these facts to develop a simple, sensitive and rapid spectrophotometric method for the determination of thiamine, without requiring 
an expensive instrumentation, needless of extraction and temperature control, and the possibility of the application of the proposed method to determination of thiamine in pharmaceutical formulations, also determining $B_{1}$ in the presence of sulphite.

\section{EXPERIMENTAL}

\section{Apparatus}

Spectral and absorbance measurements are carried out using Shimadzu UV-160 UVVisible computerized double-beam spectrophotometer. In all measurements, 1-cm matched cells are used. The $\mathrm{pH}$ measurements are carried out using HANA pH meter.

\section{Chemicals}

All chemicals used are of analytical reagent grade.

Thiamine hydrochloride (1000 $\boldsymbol{\mu g} / \mathbf{m l})$ solution. This solution was prepared by dissolving $0.1000 \mathrm{~g}$ of $\mathrm{B}_{1}$ in distilled water and the volume was completed to $100 \mathrm{ml}$ with distilled water in a volumetric flask. The solution was then transferred to a dark bottle and is stable for at least 2 days. Working solution of $100 \mu \mathrm{g} / \mathrm{ml} \mathrm{B}_{1}$ solution was prepared by an appropriate dilution of the stock solution with distilled water.

Potassium chromate solution, $8.62 \times 10^{-4} \mathrm{M}$. This solution is prepared by dissolving $0.1674 \mathrm{~g}$ of potassium chromate (Fluka) in $100 \mathrm{ml}$ distilled water in a volumetric flask. The solution was transferred to a dark bottle and it stable for at least one month. Working solution $8.62 \times 10^{-4} \mathrm{M}$ of chromate was prepared by appropriate dilution of the stock solution with distilled water.

1,5-Diphenylcarbazide solution, $1.5 \times 10^{-3}$ M. This solution is prepared by dissolving $0.0908 \mathrm{~g}$ of 1,5-diphenylcarbazide $(\mathrm{BDH})$ in $5 \mathrm{ml}$ of pure acetone, then the volume is completed $250 \mathrm{ml}$ with distilled water in a volumetric flask. This solution is stable for at least 3 days.

Sulphuric acid solution, $\mathbf{2 N}$. This solution is prepared by an appropriate dilution of the concentrated sulphuric acid solution to the mark with distilled water in a 250-ml volumetric flask.

Sodium sulphite solution. An approximately $0.1 \mathrm{~N}$ solution is prepared by dissolving a known amount of sodium sulphite anhydrous (Fluka) in distilled water containing $2 \mathrm{ml}$ of $0.01 \% \mathrm{D}(-)$ fructose as a stabilizer (Gobbi et al., 1998). This solution is standardized by iodimetry, sulphite solution with $(0.01 \% \mathrm{D}(-)$ fructose) are prepared by suitable dilutions of the standard with distilled water. A $100 \mathrm{ppm}$ sulphite solution is stable for at least 3 days.

Mercuric nitrate solution, $\mathbf{0 . 0 1}$ M. This solution is prepared by dissolving $0.8565 \mathrm{~g}$ of $0.01 \mathrm{M}$ mercuric nitrate monohydrate (Fluka) in distilled water then the volume is completed to the mark with distilled water in a $250-\mathrm{ml}$ volumetric flask.

\section{Procedure and Calibration Graph}

To a series of 25-ml calibrated flasks, an increasing volume (0.1-11.3) $\mathrm{ml}$ of $100 \mu \mathrm{g}$. $\mathrm{ml}^{-1} \quad \mathrm{~B}_{1}$ solution is transferred, followed by $2.5 \mathrm{ml}$ of sulphuric acid solution $(2 \mathrm{~N})$ and 1 $\mathrm{ml}$ of $8.62 \times 10^{-4} \mathrm{M}$ chromate solution, standing for 5 minutes, the $1 \mathrm{ml}$ of $1.5 \times 10^{-3} \mathrm{M}$ DPC reagent solution is added. After diluting the flasks with distilled water, the absorbances are measured at $543 \mathrm{~nm}$ against the reagent blank. Beer's law is obeyed over the range of concentration $0.4-40 \mu \mathrm{g} / \mathrm{ml}$ vitamin $\mathrm{B}_{1}$ (Fig. 1 ). The molar absorptivity being $1.5 \times 10^{4} 1 . \mathrm{mol}^{-1} . \mathrm{cm}^{-1}$, and the Sandall sensitivity is $0.02248 \mu \mathrm{g} . \mathrm{cm}^{-2}$. 


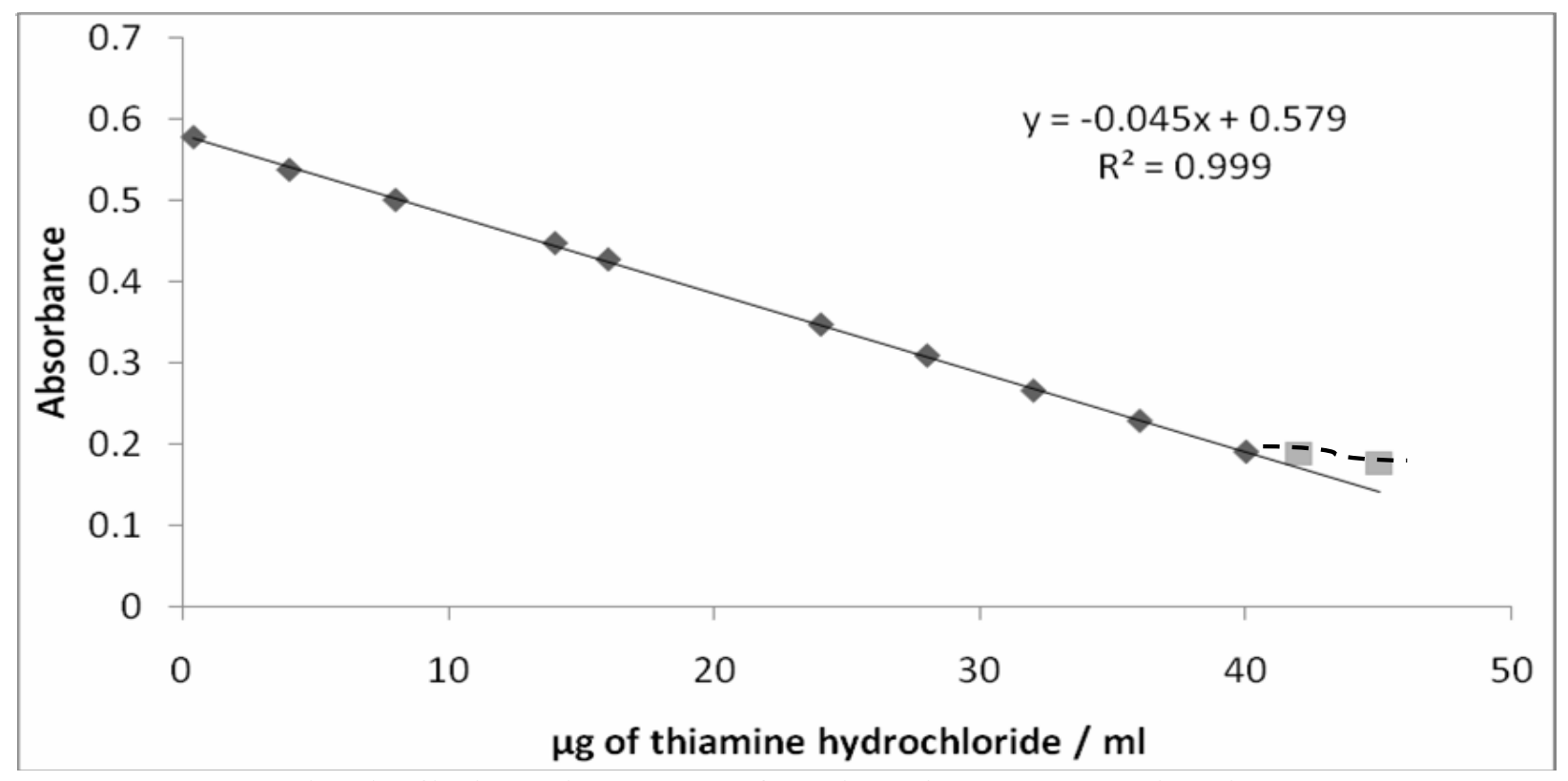

Fig. 1: Calibration graph for vitamin $B_{1}$ determination

\section{Procedure for Drugs Forms}

For tablet. At least ten tablets $\left(200 \mathrm{mg} \mathrm{B} \mathrm{B}_{1}-\mathrm{HCl} / \mathrm{tablet}\right)$ of the drug (Tetravit) were weighed, powdered and mixed well. A portion equivalent to $0.01 \mathrm{~g}$ was weighed and dissolved in $50 \mathrm{ml}$ of distilled water, shaken well, filtered and diluted with water to $100 \mathrm{ml}$ in a volumetric flask. An aliquot of the diluted drug solution was then treated as done in the recommended procedure.

For capsule. At least ten capsules $(5 \mathrm{mg} \mathrm{B}$ - $\mathrm{HCl} /$ capsule) of the drug (B-plex) were weighed. A portion equivalent to $0.01 \mathrm{~g}$ was weighed and dissolved in $50 \mathrm{ml}$ of distilled water, shaken well, filtered and diluted with water to $100 \mathrm{ml}$ in a volumetric flask, then it was proceeded as described under recommended procedure.

\section{Study of optimum conditions}

\section{RESULTS AND DISCUSSION}

The effect of various parameters on the oxidation-reduction reaction and the intensity of the coloured complex have been studied and optimum conditions have been selected.

\section{Effect of Sulphuric Acid Amount}

In order to choose the optimum amount of sulphuric acid for the reaction of thiamine hydrochloride with chromate, and the formation of a stable coloured complex between chromate and DPC, different amounts (0-5.0) $\mathrm{ml}$ of sulphuric acid (2N) are tested. The results shown in Table (1) indicate that $2.5 \mathrm{ml}$ of $2 \mathrm{~N} \mathrm{H}_{2} \mathrm{SO}_{4}$ is considered optimum, as it gives the more stable coloured complex (Sandell, 1959). Therefore, it is recommended for subsequent experiments. 
Table 1: Effect of sulphuric acid

\begin{tabular}{|c|c|c|c|}
\hline $\begin{array}{c}\text { ml of } \\
\text { sulphuric acid (2N) }\end{array}$ & Absorbance & Final pH & $\boldsymbol{\lambda} \mathbf{m a x}$ \\
\hline 0.1 & 0.349 & 2.52 & 542.5 \\
\hline 0.5 & 0.358 & 2.01 & 542.5 \\
\hline 0.7 & 0.341 & 1.88 & 541.5 \\
\hline 1.0 & 0.467 & 1.77 & 541.5 \\
\hline 1.5 & 0.533 & 1.64 & 541.5 \\
\hline 2.0 & 0.529 & 1.54 & 542.5 \\
\hline 2.5 & 0.525 & 1.41 & 543.0 \\
\hline 3.0 & 0.532 & 1.37 & 542.0 \\
\hline 3.5 & 0.532 & 1.31 & 541.0 \\
\hline 4.0 & 0.539 & 1.27 & 543.5 \\
\hline 5.0 & 0.560 & 1.15 & 544.0 \\
\hline
\end{tabular}

\section{Effect of chromate ion amount}

Different amounts of chromate (VI) ion solution $8.62 \times 10^{-4} \mathrm{M}$ with different amount (0.1-6) $\mathrm{ml}$ of $100 \mu \mathrm{g} . \mathrm{ml}^{-1}$ thiamine hydrochloride are studied and it was found from the experimental results that $1 \mathrm{ml}$ of chromate which gives higher value of determination coefficient (0.99733862) was optimum and recommended for the subsequent experiments as shown in Table (2).

Table 2: Effect of chromate (VI) ion

\begin{tabular}{|c|c|c|c|c|c|c|c|c|c|}
\hline \multirow{2}{*}{$\begin{array}{c}\text { ml of } 8.62 \times 10^{-4} \\
\text { M chromate } \\
\text { solution }\end{array}$} & \multicolumn{8}{|c|}{ Absorbance / $\mu \mathrm{g}$ thiamine hydrochloride in $25 \mathrm{ml}$} & \multirow{2}{*}{$\mathbf{r}^{2}$} \\
\hline & 10 & 30 & 50 & 70 & 100 & 200 & 400 & 600 & \\
\hline 0.5 & 0.577 & 0.552 & 0.528 & 0.519 & 0.484 & 0.453 & 0.378 & 0.299 & 0.97040045 \\
\hline 1.0 & 0.591 & 0.582 & 0.565 & 0.553 & 0.541 & 0.491 & 0.411 & 0.311 & 0.99733862 \\
\hline 1.5 & 0.628 & 0.609 & 0.591 & 0.57 & 0.561 & 0.533 & 0.481 & 0.442 & 0.94197102 \\
\hline
\end{tabular}

\section{Effect of time on the reduction of chromate (VI) ion}

A study of time effect on the reduction of chromate ion by thiamine hydrochloride has been investigated. The results shown in (Fig. 2), indicated that 5 min. reaction time was optimum because it gives lower absorbance of the colored complex and this time was recommended for the subsequent experiments. 


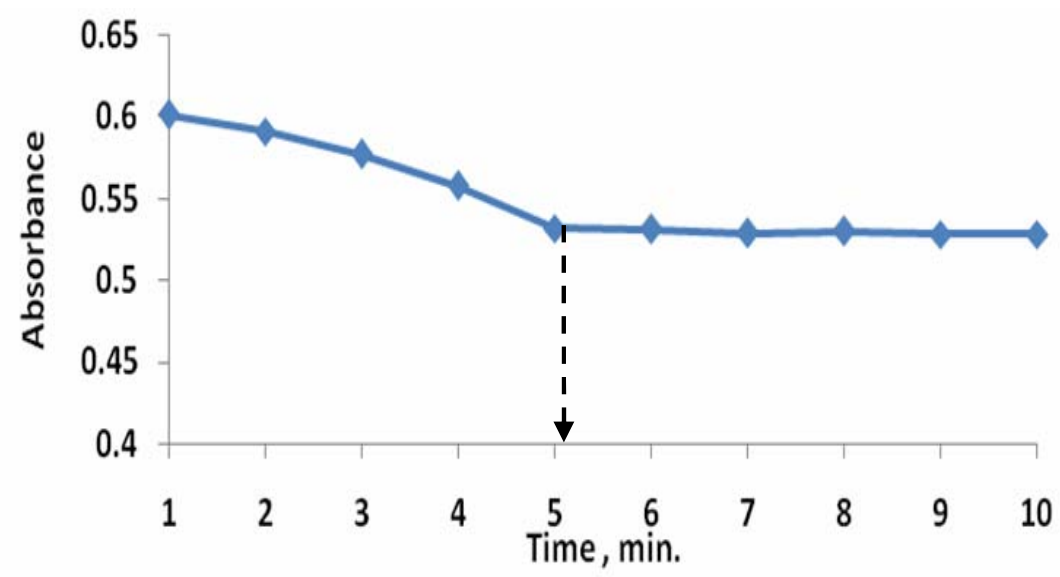

Fig. 2: Effect of time on the reducing chromate by $B_{1}$

\section{Effect of 1,5-diphenylcarbazide amount}

The effect of the amount of DPC reagent on maximum formation of the coloured complex is investigated. It was found from the experimental results that $1 \mathrm{ml}$ of DPC reagent $1.5 \times 10^{-3} \mathrm{M}$ was optimum (determination coefficient $=0.992464969$ ), and recommended for the subsequent experiments as shown in Table (3).

Table 3: Effect of 1,5-diphenylcarbazide amount

\begin{tabular}{|c|c|c|c|c|c|c|c|c|c|}
\hline $\begin{array}{c}\text { ml of } \\
\mathbf{1 . 5}^{-3} \\
\begin{array}{c}\text { M DPC } \\
\text { solution }\end{array}\end{array}$ & \multicolumn{6}{|c|}{ Absorbance / $\boldsymbol{\mu g}$ thiamine hydrochloride in 25 ml } & \multirow{2}{*}{$\mathbf{r}^{\mathbf{2}}$} \\
\cline { 2 - 10 } & $\mathbf{1 0}$ & $\mathbf{3 0}$ & $\mathbf{5 0}$ & $\mathbf{7 0}$ & $\mathbf{1 0 0}$ & $\mathbf{2 0 0}$ & $\mathbf{4 0 0}$ & $\mathbf{6 0 0}$ & \\
\hline 0.5 & 0.593 & 0.57 & 0.527 & 0.513 & 0.492 & 0.455 & 0.359 & 0.306 & 0.94668874 \\
\hline 1.0 & 0.602 & 0.593 & 0.569 & 0.551 & 0.544 & 0.490 & 0.408 & 0.313 & 0.992464969 \\
\hline 1.5 & 0.611 & 0.604 & 0.583 & 0.568 & 0.551 & 0.517 & 0.492 & 0.448 & 0.921857171 \\
\hline
\end{tabular}

\section{Effect of order of addition}

The different orders of addition were studied. The results shown in Table (4) indicate that the first order was optimum because it gives lowest absorbance value, therefore it is recommended for the subsequent experiments.

Table 4: Effect of order of addition

\begin{tabular}{|c|c|c|}
\hline Reaction components & Order number & Absorbance \\
\hline $\mathrm{B}_{1}+\mathrm{H}+\mathrm{Cr}+\mathrm{DPC}$ & $\mathrm{I}$ & 0.528 \\
\hline $\mathrm{B}_{1}+\mathrm{DPC}+\mathrm{Cr}+\mathrm{H}$ & $\mathrm{II}$ & 0.541 \\
\hline $\mathrm{B}_{1}+\mathrm{Cr}+\mathrm{H}+\mathrm{DPC}$ & $\mathrm{III}$ & 0.547 \\
\hline $\mathrm{B}_{1}+\mathrm{DPC}+\mathrm{H}+\mathrm{Cr}$ & $\mathrm{IV}$ & 0.578 \\
\hline $\mathrm{B}_{1}+\mathrm{H}+\mathrm{DPC}+\mathrm{Cr}$ & $\mathrm{V}$ & 0.588 \\
\hline $\mathrm{B}_{1}+\mathrm{Cr}+\mathrm{DPC}+\mathrm{H}$ & $\mathrm{VI}$ & 0.616 \\
\hline
\end{tabular}

$\mathrm{B}_{1}=$ Vitamin $\mathrm{B}_{1}, \mathrm{Cr}=$ Chromate, $\mathrm{H}=$ Sulphuric acid, $\mathrm{DPC}=1,5$-Diphenylcarbazide. 


\section{Development time and stability period}

To test the effect of time on the absorbance of the coloured complex for different amounts of thiamine hydrochloride at the wavelength of maximum absorption at $543 \mathrm{~nm}$, under the optimum experimental conditions, the absorbances were measured at different intervals of time. The experimental results shown in (Fig. 3) indicated that the coloured complex develops immediately and maximally after $5 \mathrm{~min}$. and the absorbance remains constant for at least $2 \mathrm{hrs}$.

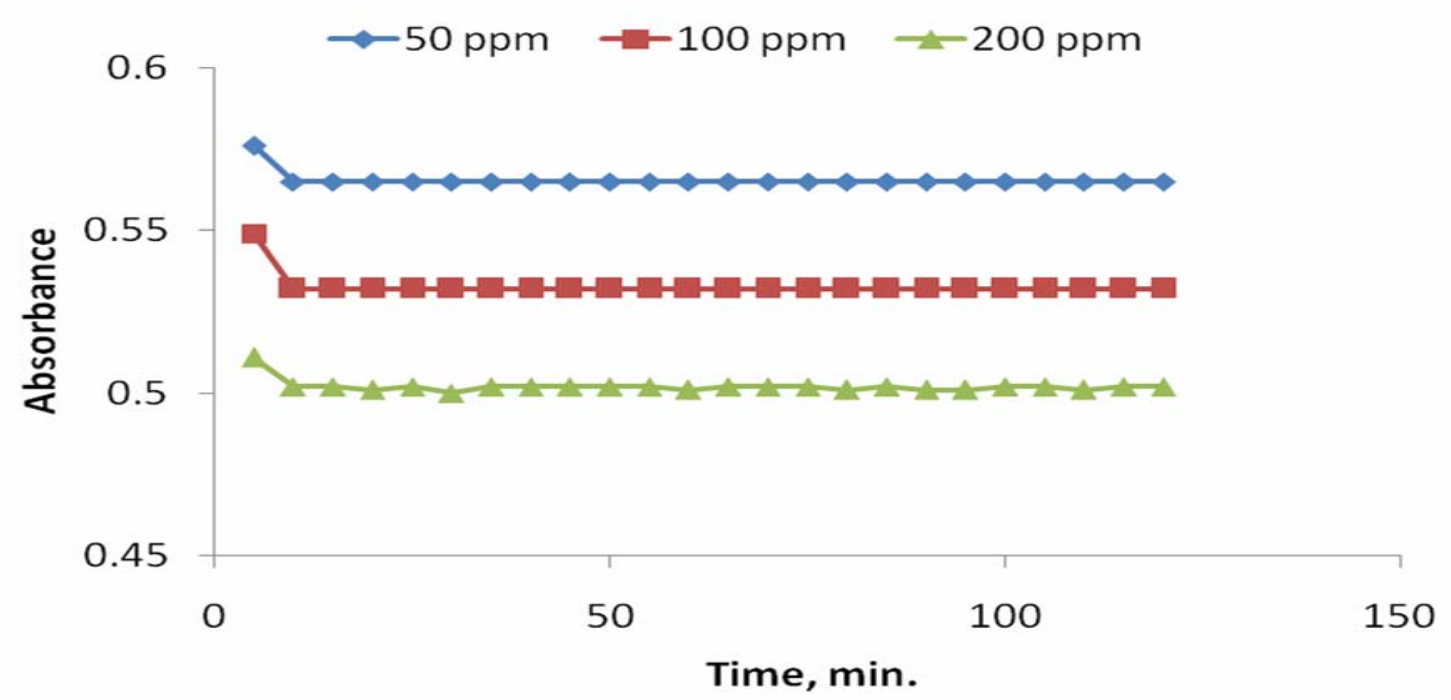

Fig. 3: Effect of time on the coloured complex.

\section{Absorption Spectra}

When vitamin $B_{1}$ is treated according to the recommended procedure, the absorption spectra is shown in (Fig. 4). The sample solution shows a maximum absorption at 542.5 $\mathrm{nm}$, characteristic of the chromate-DPC complex, in contrast to the reagent blank which shows a slight absorption at this wavelength, emphasising the need for measurements to be performed against the reagent blank.

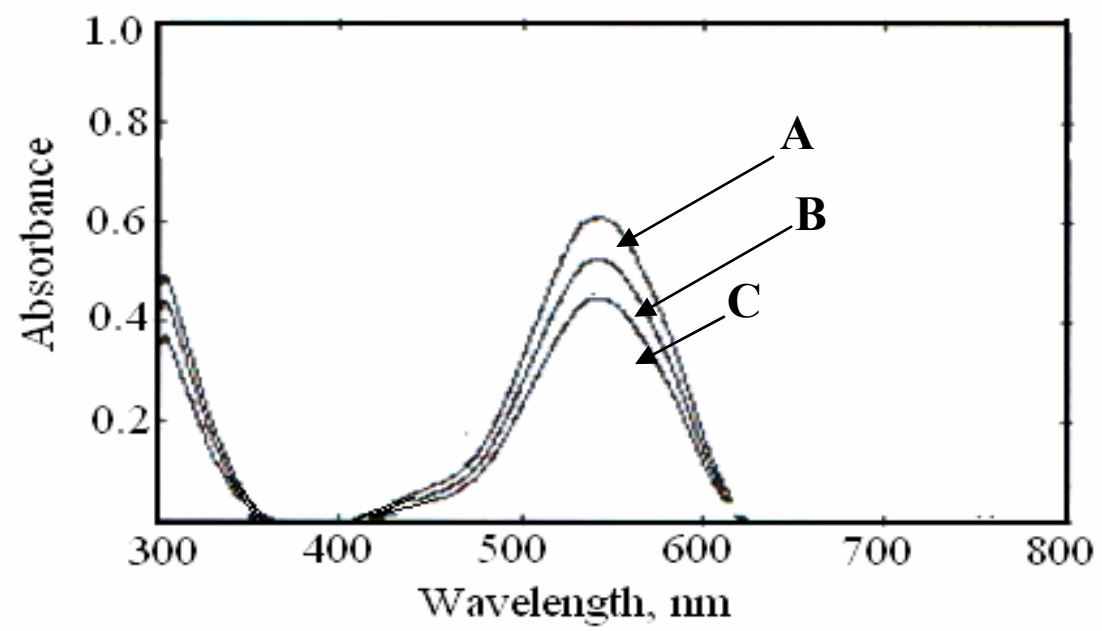

Fig. 4: Absorption spectra of (A) optimum amount of chromate against reagent blank, (B) $100 \mu \mathrm{g}$ of $\mathrm{B}_{1} / 25 \mathrm{ml}$ measured against reagent blank, (C) $350 \mu \mathrm{g}$ of $B_{1} / 25 \mathrm{ml}$ measured against reagent blank. 


\section{Accuracy and Precision}

To check the accuracy and precision of the calibration curve, thiamine hydrochloride is determined at four concentrations. The results shown in Table (5) indicate that these are reliable.

Table 5 : Accuracy and precision

\begin{tabular}{|c|c|c|}
\hline $\begin{array}{c}\text { Amount of thiamine } \\
\text { hydrochloride taken, } \\
\boldsymbol{\mu g} / \mathbf{2 5 m l}\end{array}$ & Recovery*, \% & $\begin{array}{c}\text { Relative standard } \\
\text { deviation } \boldsymbol{*} \%\end{array}$ \\
\hline 50 & 99.86 & \pm 0.34 \\
\hline 100 & 100.08 & \pm 0.57 \\
\hline 200 & 100.19 & \pm 0.31 \\
\hline 400 & 99.19 & \pm 0.32 \\
\hline
\end{tabular}

* Average of five determinations.

\section{Nature of the reaction between $B_{1}$ and chromate.}

Job's method has been used in the determination of the reaction ratio of $\mathrm{B}_{1}$ with chromate. The obtained result showed that the ratio of $B_{1}$ to chromate is $1: 2$ as in (Fig. 5).

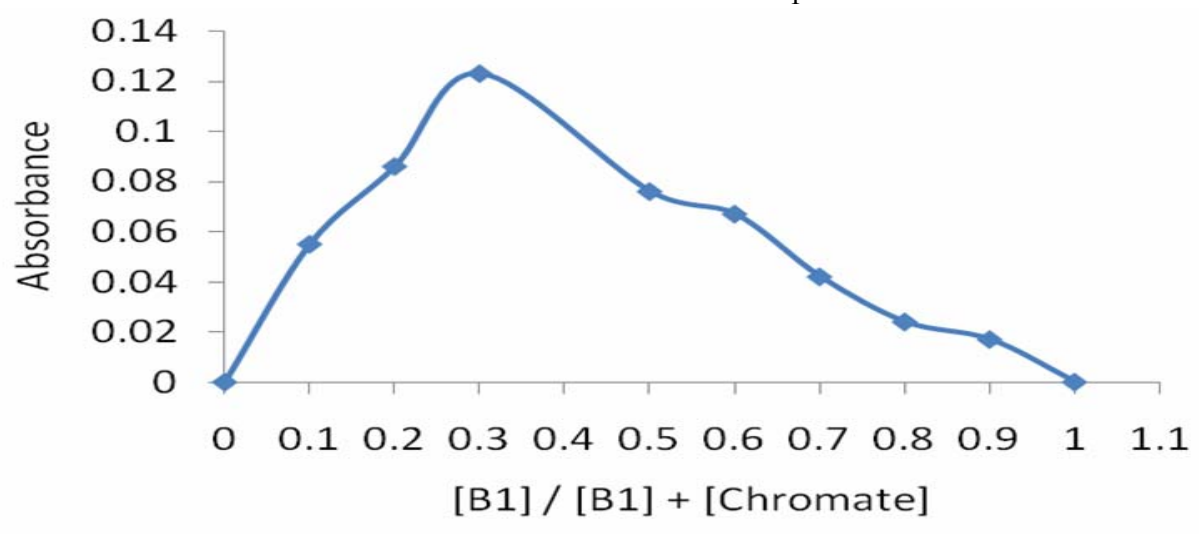

Fig. 5: Job's plot for $B_{1}$ - chromate

As a result the following reaction is suggested between vitamin $\mathrm{B}_{1}$ and chromate:

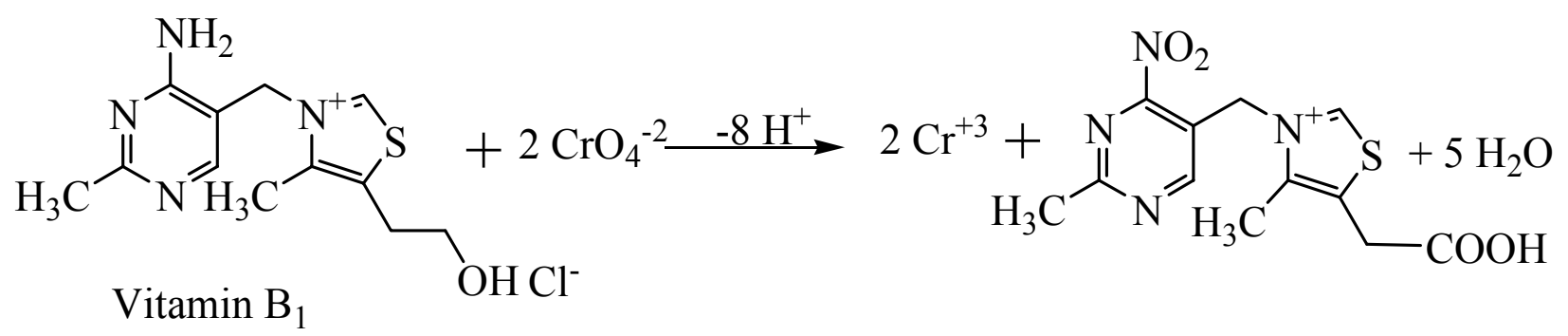


Nature of chromate- DPC complex.

The stoichiometry of the reaction is investigated using the Job's method under the optimized conditions. The result in (Fig. 6) showed that the ratio of chromate to DPC is $1: 2$

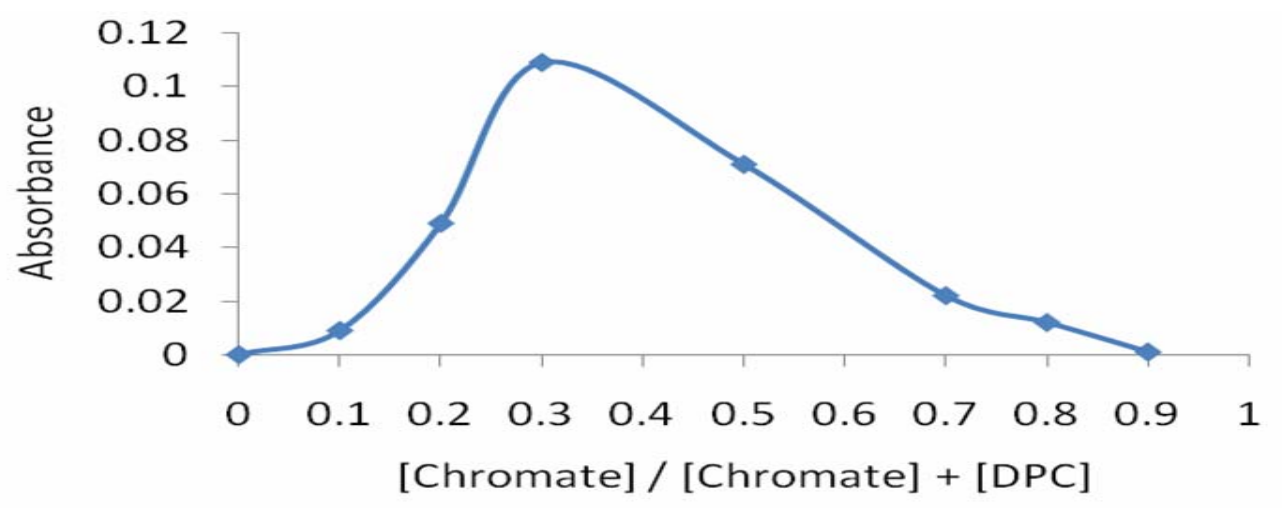

Fig. 6: Job's plot for Chromate - DPC.

\section{Effect of Interferences}

In order to test the efficiency and selectivity of the proposed method, the effect of some foreign substances (e.g., acacia, glucose, lactose, sulphite, menthol and starch) that are usually present in dosage forms were studied by adding different amounts of foreign substances to $100 \mu \mathrm{g} \mathrm{B} / 25 \mathrm{ml}$. It was observed that the studied foreign species did not interfere in the present method except in the presence of $\mathrm{SO}_{3}{ }^{2}$, which interfere seriously as in Table (6).

Table 6: Effect of interferences on the determination of $100 \mu \mathrm{g} \mathrm{B}_{1}$

\begin{tabular}{|c|c|c|c|}
\hline \multirow{2}{*}{ Interferences } & \multicolumn{3}{|c|}{ Recovery $(\%)$ of $100 \mu \mathrm{g} \mathrm{B} B_{1} / \mu \mathrm{g}$ of interference added } \\
\hline & 100 & 500 & 1000 \\
\hline Acacia & 100.38 & 99.62 & 99.44 \\
\hline Glucose & 99.62 & 100.75 & 99.25 \\
\hline Lactose & 100.19 & 100.38 & 99.06 \\
\hline Menthol & 99.81 & 101.32 & 100.75 \\
\hline Starch & 99.62 & 100.19 & 100.56 \\
\hline Sulphite & 62.22 & 47.93 & 34.59 \\
\hline
\end{tabular}

\section{Determination of $\mathrm{B}_{1}$ in Presence of Sulphite}

As sulphite $\left(\mathrm{SO}_{3}{ }^{-2}\right)$ was clearly interfered by attacking thiamine at the methylene bridge in the structure, cleaving the pyrimidine ring from the thiazole ring, the proposed method has been developed for determining thiamine hydrochloride in presence of sulphite. This method depends on masking sulphite by mercuric ion $\left(\mathrm{Hg}^{2+}\right)$ as a masking agent (Williams, 1979) using the following experiments:

To a series of $25-\mathrm{ml}$ calibrated flasks, $1 \mathrm{ml}$ of $100 \mu \mathrm{g} . \mathrm{ml}^{-1} \mathrm{~B}_{1}$ solution are transferred, followed by $2.5 \mathrm{ml}$ of sulphuric acid solution $(2 \mathrm{~N})$ and $(50-500) \mu \mathrm{g} / \mathrm{ml}$ of 
sulphite $\mathrm{SO}_{3}^{-2}$, then an increasing volume (0.5-1.5) $\mathrm{ml}$ of $0.01 \mathrm{M}$ mercuric nitrate solution have been added, shacked well then, standing for 5 minutes. Finally, $1 \mathrm{ml}$ of $8.63 \times 10^{-4} \mathrm{M}$ chromate solution and $1 \mathrm{ml}$ of $1.5 \times 10^{-3} \mathrm{M}$ DPC reagent solution have been added. After the dilution of the flasks with distilled water, the absorbance is measured at $543 \mathrm{~nm}$ against the reagent blank as shown in Table (7).

\section{Table 7: Determination of $100 \mu \mathrm{g} \cdot \mathrm{ml}^{-1}$ of thiamine hydrochloride in presence of sulphite}

\begin{tabular}{|c|c|c|c|c|c|c|c|c|c|}
\hline \multirow{2}{*}{$\begin{array}{l}\mathrm{ml} \text { of } \mathbf{0 . 0 1} \mathrm{M} \\
\mathrm{Hg}^{2+} \text { solution }\end{array}$} & \multicolumn{9}{|c|}{ Absorbance */ $\mu$ g of Sulphite present in $25 \mathrm{ml}$} \\
\hline & 50 & 75 & 100 & 150 & 200 & 250 & 300 & 400 & 500 \\
\hline 0.5 & 0.487 & 0.477 & 0.480 & 0.479 & 0.476 & 0.489 & 0.478 & 0.481 & 0.471 \\
\hline 1.0 & 0.538 & 0.534 & 0.529 & 0.535 & 0.529 & 0.534 & 0.537 & 0.533 & 0.527 \\
\hline 1.5 & 0.612 & 0.612 & 0.611 & 0.613 & 0.622 & 0.619 & 0.621 & 0.624 & 0.632 \\
\hline
\end{tabular}

* Absorbance without $\mathrm{SO}_{3}^{-2}=0.531$

The results given in Table (7) indicate that a complete removal of sulphite $(50-500 \mu \mathrm{g})$ from $B_{1}$ is achieved using $1 \mathrm{ml}$ of $(0.01 \mathrm{M})$ mercuric nitrate solution as it gave the nearest absorbance in comparison to the $\mathrm{B}_{1}$ solution alone.

\section{Application of the Method}

The proposed method was successfully applied to the determination of $B_{1}$ in its pharmaceutical preparations (tablet and capsule). The results which are shown in Table (8) indicate that a good recovery was obtained.

Table 8: Analytical applications

\begin{tabular}{|c|c|c|c|c|}
\hline \multirow[b]{2}{*}{$B_{1}$ amount, $\mu \mathrm{g}$} & \multicolumn{4}{|c|}{ Recovery $(\%)$ of $B_{1} *$} \\
\hline & $\begin{array}{r}(200 \mathrm{mg} / \text { tablet }) \\
\text { Iraq }\end{array}$ & NDI- & $\begin{array}{r}\text { (5mg/capsule) } \\
\text { Iraq }\end{array}$ & SDI- \\
\hline 50 & 100.57 & & 99.71 & \\
\hline 100 & 99.96 & & 99.89 & \\
\hline 250 & 100.41 & & 100.66 & \\
\hline
\end{tabular}

* Average of five determinations.

The calculated value of t-test (Christian, 2004), did not exceed the theoretical values at the $95 \%$ confidence level for five degrees of freedom when the proposed method has been compared with literature method (Jahanbakhsh and Bahman, 2005) as shown in Table (9). 
Table 9: The results of $t$-test analysis

\begin{tabular}{|c|c|c|}
\hline Drug & Pharmaceutical preparation & t-test \\
\hline $\mathrm{B}_{1}$ (NDI-Iraq) & Tablet & 0.475 \\
\hline
\end{tabular}

\section{Comparison of the Methods}

Table (10) shows the comparison between some of analytical variables for the present method with that of other literature spectrophotometric methods.

Table 10: Comparison of the methods

\begin{tabular}{|c|c|c|c|}
\hline Analytical parameters & Present method & $\begin{array}{l}\text { Literature method } \\
\text { (Zhiping et al., 2012) }\end{array}$ & $\begin{array}{l}\text { Literature method } \\
\text { (Mahmure and } \\
\text { Ikbal, 2002) }\end{array}$ \\
\hline Method & Chromate-DPC & 12-Tungstophosphoric acid & $\begin{array}{l}\text { Second derivative } \\
\text { spectrophotometry }\end{array}$ \\
\hline $\mathrm{pH}$ & 1.41 & $0-1.0$ & ------ \\
\hline Kind of acid & $2 \mathrm{~N} \mathrm{H}_{2} \mathrm{SO}_{4}$ & $\begin{array}{ll}------ \\
\end{array}$ & $0.1 \mathrm{~N} \mathrm{HCl}$ \\
\hline$\lambda_{\max }(\mathrm{nm})$ & 543 & 335 & 228.9 \\
\hline Reaction time (min) & 5 & ------ & ------- \\
\hline Stability period (minutes) & 120 & ------- & ------- \\
\hline Beer's law range (ppm) & $0.4-40$ & $0.25-1.75$ & Up to 20 \\
\hline Molar absorptivity $\left(1 . \mathrm{mol}^{-1} \cdot \mathrm{cm}^{-1}\right)$ & $1.5 \times 10^{4}$ & -------- & -------- \\
\hline R.S.D. $(\%)$ & $\pm 0.31- \pm 0.57$ & $1.1-3.4$ & ------- \\
\hline Colour of the product & Pink-violet & 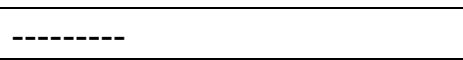 & -------- \\
\hline Application of the method & $\begin{array}{l}\text { Pharmaceutical } \\
\text { preparations }\end{array}$ & Urine samples and $B_{1}$ tablets & $\begin{array}{l}\text { Synthetic mixture } \\
\text { and commercial } \\
\text { pharmaceutical } \\
\text { preparations }\end{array}$ \\
\hline
\end{tabular}

The results indicate that the proposed method is sensitive and can be applied successfully to the determination of $\mathrm{B}_{1}$ in pharmaceutical preparations.

\section{CONCLUSION}

A simple, sensitive, selective and inexpensive spectrophotometric method for the determination of $\mathrm{B}_{1}$ has been carried out by the rapid reduction of known amount of chromate $\mathrm{CrO}_{4}{ }^{-2}$ in the presence of $\mathrm{B}_{1}$ in acidic medium of sulphuric acid. Then the excess of chromate is measured via 1,5-diphenylcarbazide which gives a pink-violet, watersoluble and stable complex, which exhibit minimum absorption at $543 \mathrm{~nm}$. Beer's law is obeyed in the concentration range of $10-1000 \mu \mathrm{g} / 25 \mathrm{ml}$ vitamin $\mathrm{B}_{1}$ with a molar absorptivity of $1.5 \times 10^{4} 1 . \mathrm{mol}^{-1} . \mathrm{cm}^{-1}$, Sandell's sensitivity index of $0.02248 \mu \mathrm{g} . \mathrm{cm}^{-2}$ and a relative standard deviation of $\pm 0.23 \%$ to $\pm 0.57 \%$ depending on the concentration level. The present method has been developed for the determination of thiamine hydrochloride in the presence of sulphite. The proposed method has been applied successfully to the determination of vitamin $B_{1}$ in pharmaceutical preparations. 


\section{REFERENCES}

Aberásturi, F.J.; Jiménez, A.I.; Arias, J.J.; Jiménez, F. (2002). Simultaneous spectrophotometric determination of folic acid, pyridoxine, riboflavin, and thiamine by partial least-squares regression. Anal. Lett., 35(10), 1677-1691.

Barrales, O.; Córdova, M.L.; Díaz, M. (1998). A selective optosensor for UV spectrophotometric determination of thiamine in the presence of other vitamins B. Anal. Chem. Acta., 376(2), 227-233

Begley, T.P.; Chatterjee, A.; Hanes, J.W.; Hazra, A.; Ealick, S.E. (2008). Cofactor biosynthesis - still yielding fascinating new biological chemistry. Curr. Opin. Chem. Biol., 12(2), 118-125.

Bettendorff, L.; Mastrogiacomo, F.; Kish, S.J.; Grisar, T. (1996). Thiamine, thiamine phosphates and their metabolizing enzymes in human brain. J. Neurochem., 66 (1), 250-258.

Bettendorff, L.; Wins, P. (2009). Thiamine diphosphate in biological chemistry : new aspects of thiamine metabolism, especially triphosphate derivatives acting other than as cofactors. FEBS J., 276(11), 2917-2925.

Bettendorff, L; Wirtzfeld, B.; Makarchikov, AF, Mazzucchelli, G.; Frédérich, M.; Gigliobianco, T.; Gangolf, M.; De Pauw, E.; Angenot, L.; Wins, P. (2007). Discovery of a natural thiamine adenine nucleotide. Nature Chem. Biol., 3(4), 211-212.

British Pharmacopoeia, CDROM, (2007). 3rd ed., System Simulation Ltd, Stationary Office, London.

Calatayud, J.; Dănet, A. (1994). FIA-spectrophotometric determination of thiamine after UV-irradiation. Talanta, 41(12), 2147-2151.

Christian, G.D. (2004). "Analytical Chemistry". 6th ed. John Wiley and Sons Inc., New York, pp. 83-99.

Clezio, A.; Pereira, A.V.; Costa-Neto C.O.; Fatibello-Filho, O. (1999). Flow-injection spectrophotometric determination of vitamin $\mathrm{B}_{1}$ (thiamine) in multivitamin preparations. Lab. Robotics Autom., 11(1), 45-50.

Gobbi, G.; Zappia, G.; Sabbioni, C. (1998). Sulphite quantification on damaged stones and mortars. Atmos. Environ., 32(4), 783-789.

Jahanbakhsh, G.; Bahman, A. (2005). Simultaneous spectrophotometric determination of group B vitamins using parallel factor analysis: PARAFAC. J. Chinese Chem. Soc., 52, 1123-1129.

Javier, L.; María, L.F.; Antonio, M. (2005). Implementation of flow-through solid phase spectroscopic transduction with photochemically induced fluorescence: determination of thiamine. Anal. Chem. Acta, 535(1-2), 161-168.

Kappler, U.; Bennett, B.; Retheier, J.; Schwarz, G.; Deutzmznn, R.; Mcewan, A.; Dahl, C. (2000). Sulphite: cytochrome c oxidoreductase from Thiobacillus novellas. J. Biol. Chem., 275(18), 13202-13212.

Khan, M.A.; Jin, S.O.; Lee, S.H.; Chung, H.Y. (2009). Spectrofluorimetric determination of vitamin $B_{1}$ using horseraddish peroxidase as catalyst in the presence of hydrogen peroxide. Luminescence, 24(2), 73-78.

Mahmure, O.; Ikbal, K. (2002) .Determination of ternary mixtures of vitamins $\left(\mathrm{B}_{1}, \mathrm{~B}_{6}\right.$, $\mathrm{B}_{12}$ ) by zero-crossing derivative spectrophotometry. Turk. J. Chem., 26, 385 -391. 
Makarchikov, A.F.; Lakaye, B.; Gulyai, I.E.; Czerniecki, J.; Coumans, B.; Wins, P.; Grisar, T.; Bettendorff, L. (2003). Thiamine triphosphate and thiamine triphosphatase activities: from bacteria to mammals. Cell Mol. Life Sci., 60(7), 1477-1488.

Marczenko, Z.; (1976). "Spectrophotometric Determination of Elements". John Wiley and Sons, Inc., pp. 213-219.

Ozdemir, D.; Dinc, E. (2004). Determination of thiamine $\mathrm{HCl}$ and pyridoxine $\mathrm{HCl}$ in pharmaceutical preparations using UV-visible spectrophotometry and genetic algorithm based multivariate calibration methods. Chem. Pharm. Bul. l (Tokyo), 52(7), 810-817.

Rocha, F.; Filho, O.; Reis, B. (2003). A multicommuted flow system for sequential spectrophotometric determination of hydrosoluble vitamins in pharmaceutical preparations. Talanta, 59, 191-200.

Sandell, E.B. (1959). "Colorimetric Determination of Trace of Metals". 3rd ed. Interscience Puplishers Inc. New York, pp. 178-400.

Shaopu, L. ; Zhuyuan, Z.; Qin, L.; Hongqun, L.; Wenxu, Z. (2002). Spectrophotometric determination of vitamin $\mathrm{B}_{1}$ in a pharmaceutical formulation using triphenylmethane acid dyes. J. Pharm. Bio. Anal., 30(3), 685-694

Spinazzi, M.; Angelini, C.; Patrini, C. (2010). Subacute sensory ataxia and opticneuropathy with thiamine deficiency, Nat. Rev. Neurol., 6, 288-93.

Thornalley, P.J. (2005). The potential role of thiamine (vitamin B(1)) in diabetic complications. Curr Diabetes Rev., 1(3), 287-98.

Webb, M.E.; Marquet, A.; Mendel, R.R.; Rebeille, F.; Smith, A.G. (2007). Elucidating biosynthetic pathways for vitamins and cofactors. Nat. Prod. Rep., 24(5), 9881008.

Williams, W.J. (1979). "Handbook of Anion Determination". Butterworth and Co (publisher), pp. 588-590,601-603.

Yahong, C.; Fengshou, T. (2010). Enzymatic catalytic spectrophotometric determination of thiamine in food. Food Anal. Methods, 3(1), 7-11.

Zhiping, C. ; Shaopu, L.; Zhongfang, L.; Xiaoli, H. (2012). Determination of vitamin $B_{1}$ with 12-tungstophosphoric acid by resonance Rayleigh scattering method. Anal. Methods, 4, 434-438. 